University of Nebraska - Lincoln

DigitalCommons@University of Nebraska - Lincoln

2012

\title{
Wetland and riparian plant communities at risk of invasion by transgenic herbicide-resistant Agrostis spp. in central Oregon
}

\author{
Michael A. Bollman \\ United States Environmental Protection Agency, bollman.mike@epa.gov \\ Marjorie J. Storm \\ Dynamac Corporation \\ George A. King \\ Dynamac Corporation \\ Lidia S. Watrud \\ United States Environmental Protection Agency
}

Follow this and additional works at: https://digitalcommons.unl.edu/usepapapers

Bollman, Michael A.; Storm, Marjorie J.; King, George A.; and Watrud, Lidia S., "Wetland and riparian plant communities at risk of invasion by transgenic herbicide-resistant Agrostis spp. in central Oregon" (2012). U.S. Environmental Protection Agency Papers. 97.

https://digitalcommons.unl.edu/usepapapers/97

This Article is brought to you for free and open access by the U.S. Environmental Protection Agency at DigitalCommons@University of Nebraska - Lincoln. It has been accepted for inclusion in U.S. Environmental Protection Agency Papers by an authorized administrator of DigitalCommons@University of Nebraska - Lincoln. 


\title{
Wetland and riparian plant communities at risk of invasion by transgenic herbicide-resistant Agrostis spp. in central Oregon
}

\author{
Michael A. Bollman • Marjorie J. Storm • \\ George A. King $\cdot$ Lidia S. Watrud
}

Received: 20 April 2011/Accepted: 17 December 2011/Published online: 24 January 2012

(C) Springer Science+Business Media B.V. (Out Side the USA) 2012

\begin{abstract}
Creeping bentgrass (Agrostis stolonifera) and redtop (A. gigantea) are introduced turfgrasses that are naturalized throughout the northern U.S. Interest in creeping bentgrass has risen following the 2003 escape of a genetically modified (GM), herbicide-resistant cultivar near Madras, Oregon. The objectives of this study were to characterize the floristic attributes of the plant communities associated with naturalized Agrostis populations in the Madras area, and to identify plant communities at risk of invasion by transgenic Agrostis. Vegetation data collected from 62 stratified random vegetation plots with and without $A$. stolonifera and A. gigantea identified 11 distinct plant communities. Community composition was strongly correlated with an indirect soil moisture index based on the wetland status of individual species. Results indicate that wetland plant communities are at the highest risk of invasion by
\end{abstract}

Electronic supplementary material The online version of this article (doi:10.1007/s11258-011-0015-z) contains supplementary material, which is available to authorized users.

M. A. Bollman $(\bowtie) \cdot$ L. S. Watrud

United States Environmental Protection Agency, National Health and Environmental Effects Research Laboratory, 200 SW 35th Street, Corvallis, OR 97333, USA

e-mail: bollman.mike@epa.gov

M. J. Storm · G. A. King

Dynamac Corporation, 200 SW 35th Street,

Corvallis, OR 97333, USA transgenic A. stolonifera. Also, inter-specific gene flow to A. gigantea could affect additional habitats and plant communities where $A$. stolonifera is not found. Both A. stolonifera and A. gigantea were invasive in wetland and riparian settings in the Madras study area, and introducing glyphosate (e.g., Roundup ${ }^{\circledR}$, Rodeo ${ }^{\circledR}$ ) herbicide tolerance into these populations would eliminate the primary means of control for these species.

Keywords Agrostis stolonifera - Agrostis gigantea . Creeping bentgrass $\cdot$ Redtop $\cdot$ Genetically modified Invasive species $\cdot$ Soil moisture

\section{Introduction}

Invasive plants have caused significant negative ecological effects in the U.S. For example, kudzu (Pueraria montana) has overgrown native vegetation in the southeast, saltcedar (Tamarix spp.) has lowered water tables in riparian areas in the southwest, cheatgrass (Bromus tectorum) has increased wildfire frequencies in western rangelands, and cordgrass (Spartina anglica) has transformed open mudflats into dense marshes in Pacific Northwest estuaries (Weber 2003). Control efforts for invasive species are often expensive and/or ineffective (Weber 2003). Introducing herbicide tolerance into an invasive species can confer a selective advantage that further complicates control efforts (Hancock 2003). Use of herbicides near 
surface water is frequently restricted, and glyphosate (formulated for use near aquatic systems; e.g., Rodeo $^{\circledR}$, AquaMaster ${ }^{\circledR}$ ) is the most commonly used herbicide in wetlands and riparian areas, due to its effectiveness, low toxicity, and rapid inactivation. While adverse effects on native plant communities from transgenic herbicide-resistant invasive plants have not been reported, the possible consequences of such escapes, e.g., reduced native species abundance or diversity due to an inability to control the invasive species, have been discussed in the scientific literature [e.g., (Hancock 2003)].

The ecology of A. stolonifera has been welldocumented in its native Europe (MacBryde 2005), but few such studies have been completed with either A. stolonifera or A. gigantea in North America. Given that A. stolonifera is widely naturalized and escapes of GM cultivars have been documented, there is a need for information on the plant communities and habitats with which it is associated. The demonstration of inter-specific gene flow into naturalized populations of A. gigantea in the Madras, Oregon area (Watrud et al. 2004), coupled with the contrasting ecological tolerances of A. gigantea, warrant investigation into the ecology of this species as well. This study builds upon previous studies of transgenic Agrostis in the Madras area. However, whereas previous studies demonstrated gene flow from GM A. stolonifera crop fields into naturalized Agrostis populations (Watrud et al. 2004), and documented establishment (Reichman et al. 2006) and persistence (Zapiola et al. 2008) of transgenic Agrostis plants in the environment; the objectives of this study were to characterize the floristic attributes of the plant communities associated with naturalized Agrostis populations in the Madras area, and to describe the plant communities at risk of invasion by transgenic Agrostis. To accomplish these objectives we compare plant communities, habitats, and Agrostis species using environmental, disturbance, and vegetation metrics.

\section{Methods}

Study area

Plant community data were collected in an area of approximately $250 \mathrm{sq} \mathrm{mi}$ centered on the town of Madras (lat 44.63345, lon -121.12949), which is located in central Oregon east of the Cascade mountain range (Fig. 1). The study area has been described in previous publications (Reichman et al. 2006; Watrud et al. 2004; Zapiola et al. 2008). In brief, it consists of the town of Madras, bordered on the north, west, and south by agricultural croplands served by a network of irrigation canals originating from the Deschutes River; and bordered on the east by the Crooked River National Grassland. The croplands are surrounded by the arid shrub-steppe typical of this part of the Interior Columbia Basin. The average annual precipitation at Madras is $26.2 \mathrm{~cm}$.

History of transgenic herbicide-resistant creeping bentgrass in the study area

In 2002, eight crop fields (totaling 162 ha) of Roundup Ready ${ }^{\circledR}$ creeping bentgrass, genetically modified to incorporate the cp4 epsps transgene for glyphosate resistance, were planted in a 4,452 ha "control zone" on the Agency Plains just north of Madras. In June 2003, the crop fields flowered for the first time, releasing transgenic pollen into the environment. During July-September 2003 we collected seeds from existing naturalized populations of A. stolonifera and A. gigantea in the area to monitor gene flow (Watrud et al. 2004). Over 300 plants carrying the cp4 epsps transgene (out of about 960,000 tested seedlings) were grown from seeds from 16 of 30 A. stolonifera and 13 of 39 A. gigantea populations tested, showing gene flow into resident Agrostis populations through both intra-specific and inter-specific hybridization. From May 2004 through March 2005 we surveyed resident Agrostis populations for the presence of transgenic plants that might have become established following the 2003 release. We found nine established transgenic plants, resulting from both hybridization and crop seed loss (Reichman et al. 2006). In June 2004 the GM bentgrass crop fields were taken out of production, but transgenic plants persisted in the area (Zapiola et al. 2008).

\section{Agrostis survey}

From 2003 through 2005 over two hundred resident Agrostis populations were identified within the Madras study area, including about 115 populations of A. stolonifera, and 95 populations of A. gigantea, with both species occurring at several locations. Most 
Fig. 1 Madras area plant community plot locations $(n=62)$, labeled by habitat: Creek, Canal, Deschutes, and Ditch

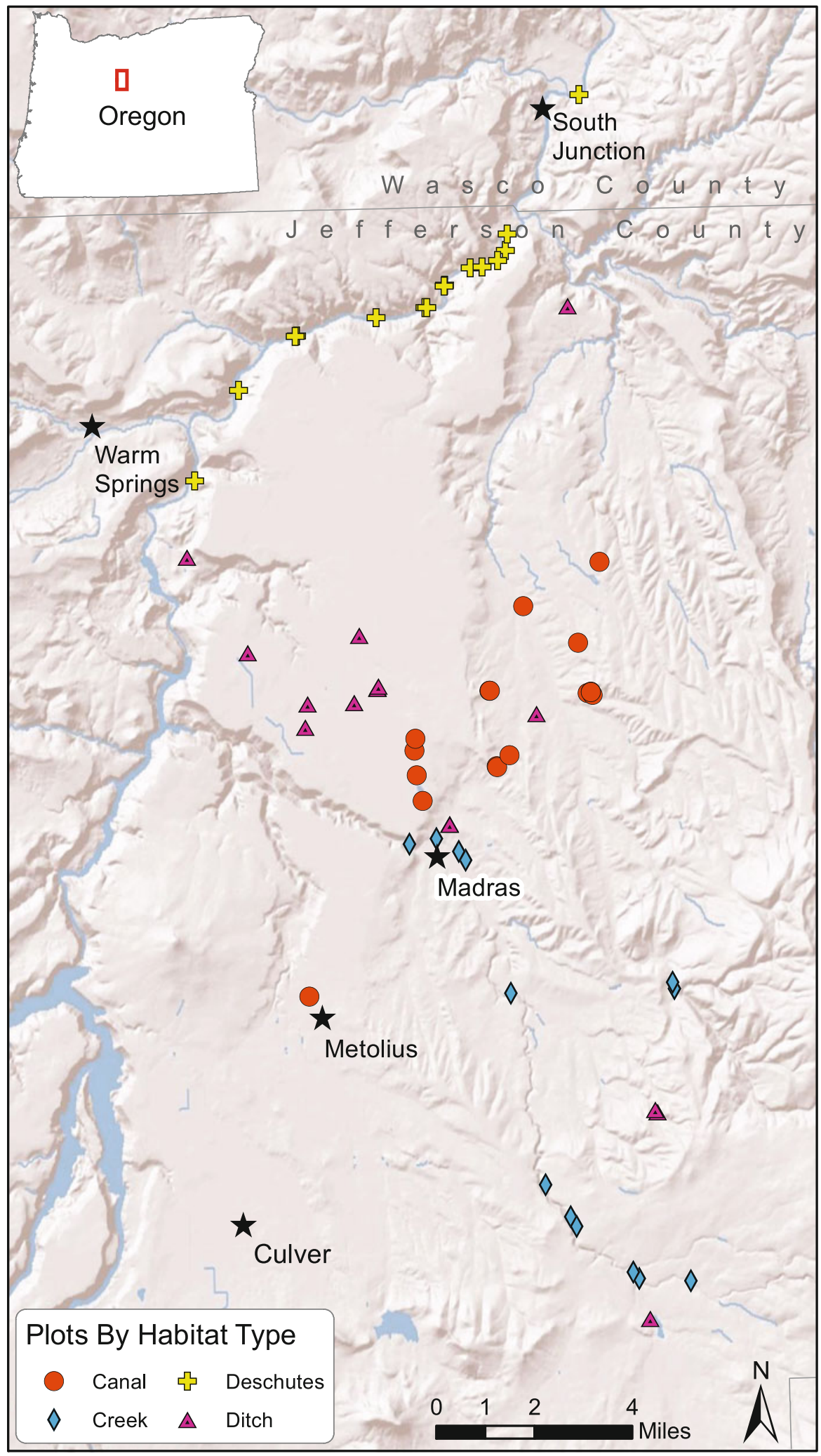


populations were found along waterways. While conducting Agrostis surveys it became apparent that many of the populations occurred in relatively distinct physical and ecological settings, which we termed "habitats". All Agrostis populations were assigned to one of the following four habitats: (1) riparian areas along Willow Creek, Mud Springs Creek, Trout Creek, or Dry Creek ("Creek"), (2) banks of irrigation supply canals ("Canal"), (3) riparian areas along the Deschutes River ("Deschutes"), or (4) ditches, springs, ponds, and other wetlands ("Ditch").

\section{Plot sampling}

Plant community data were collected at 62 plots during 2005 and 2006 (Fig. 1; Table 1). We collected data at three complimentary sets of plots: (1) locations where the transgenic herbicide-resistant (GM) Agrostis plants identified in Reichman et al. (2006) became established ( $n=8)$, (2) locations where Agrostis was found, but where no GM plants became established $(n=36)$, and (3) locations as similar in all respects as possible to the Agrostis plots but which had no Agrostis $(n=18)$. The non-GM Agrostis plots were further divided into 3 groups: (1) plots that had only $A$. gigantea $(n=10),(2)$ plots that had only A. stolonifera $(n=13)$, and (3) plots where both species were present $(n=13)$. Plots for each non-GM Agrostis plot type were selected at random from all populations found in the prior Agrostis survey, stratified by habitat to optimize representation of plot types among habitats (Table 1). Following Agrostis plot selection, nonAgrostis plots were likewise established in locations with similar elevation, topography, land use, and vegetative cover type.

At each plot, twelve $0.5 \mathrm{sq} \mathrm{m}$ sampling quadrats $(50 \times 100 \mathrm{~cm}$ rectangle $)$ were placed in 3 parallel transects of 4 quadrats each, with one transect along the water's edge or topographic low point (the plot baseline), and the other two transects at 3 and $6 \mathrm{~m}$ upslope from it. Quadrats in transects were placed $5 \mathrm{~m}$ apart. Visual cover estimates (as a percent of the 2-dimensional quadrat area) were made for each vascular plant taxon in each quadrat. Cover in quadrats was averaged to generate plot means and transect means. Across all plots, 189 taxa were identified to species, and 44 were identified to genus or other taxonomic category. All 233 plant taxa found in any of the quadrats are listed in Online Resource 1. Nomenclature follows the PLANTS database (USDA-NRCS 2010). Data on plot environmental attributes (aspect, bare ground, gravimetric soil moisture, and land use) and disturbance characteristics (dredging, grazing/ mowing, spraying/burning, roads, trails, trash, and water level fluctuation) were collected for all plots.

Soil samples were collected at all plots between June 27 and September 8, 2006, reflecting conditions during the driest part of the year. Samples were collected from each of the 4 quadrats, then composited to represent each of the three transects. We measured gravimetric soil moisture (GSM) for all soil samples, and concentrations of iron, nitrate, and ammonium were measured by the Oregon State University Central Analytical Laboratory. Iron content of samples was based on analyses made with a Perkin-Elmer OPTIMA 3000DV ICP spectrophotometer, while nitrate and ammonium were analyzed using an Alpkem RFA 300.

\section{Data analysis}

We assigned all species a wetland indicator status (included in Online Resource 1) using a regionally specific list of species that are likely to be found in
Table 1 Number of plots by plot type and habitat

\begin{tabular}{lllllll}
\hline Habitat & Plot type & \multicolumn{2}{c}{ Total } \\
\cline { 2 - 6 } & $\begin{array}{l}\text { Agrostis } \\
\begin{array}{l}\text { gigantea } \\
\text { (AG) }\end{array}\end{array}$ & $\begin{array}{l}\text { Agrostis } \\
\text { stolonifera } \\
\text { (AS) }\end{array}$ & $\begin{array}{l}\text { A. gigantea, } \\
\text { A. stolonifera } \\
\text { (AG/AS) }\end{array}$ & $\begin{array}{l}\text { GM } \\
\text { Agrostis } \\
\text { (GM) }\end{array}$ & $\begin{array}{l}\text { Non- } \\
\text { Agrostis } \\
\text { (NON) }\end{array}$ & \\
\hline Creek & 2 & 1 & 6 & 0 & 4 & 13 \\
Canal & 3 & 4 & 2 & 4 & 4 & 17 \\
Deschutes & 2 & 5 & 3 & 0 & 5 & 15 \\
Ditch & 3 & 3 & 2 & 4 & 5 & 17 \\
Total & 10 & 13 & 13 & 8 & 18 & 62 \\
\hline
\end{tabular}


wetlands (USFWS 1996). Taxa identified only to genus were considered to be non-wetland (upland) taxa. We then calculated the proportion of the total vegetation cover that was comprised of wetlandaffiliated species (FAC or wetter) for each plot: relative wetland cover, $\mathrm{RWC}=$ (sum wetland species cover/total cover $) \times 100$. We also calculated an indirect numerical soil moisture index (SMI) for each plot based on wetland indicator status $(\mathrm{OBL}=1$, $\mathrm{FACW}=2, \quad \mathrm{FAC}=3, \quad \mathrm{FACU}=4, \quad$ and UPL/ unknown $=5$ ) and cover of each taxon in the plot. The sum of those values for all the taxa in the plot was divided by the total cover of all taxa in the plot (Wentworth et al. 1988). SMI values for a plant community can range from 1.0 (all plants present are obligate wetland species) to 5.0 (all plants present are upland species). Although this metric is similar to RWC, it differs in that it weights wetland-affiliated species by their fidelity to wetland habitats.

We also calculated relative introduced cover, RIC $=$ (sum introduced species cover/total cover $) \times$ 100. Native (indigenous) or introduced (non-indigenous) status in the Pacific Northwest region was determined for each species, and for taxa identified only to genus where all species in the genus are either all native or all introduced in the region (included in Online Resource 1), using a regional flora (Hitchcock et al. 1969). Native/introduced assignments included 126 native, 78 introduced, and 29 unknown.

PC-ORD version 5.0 (McCune and Mefford 2006) and SAS/STAT software Version 9.2 of the SAS system for Windows were used to analyze the data. We used non-parametric procedures for cover analyses because the data were not normally distributed. Cover data were square root transformed before ordination to retain the information value of less abundant taxa (McCune and Grace 2002). To incorporate the correlation among the three transects at each of the 62 plots when comparing variables at the transect scale across all plots, the model parameters were estimated by a maximum likelihood approach assuming a multivariate normal distribution for the three transects within a plot with either a general or Toeplitz variance-covariance structure.

Candidate plant community types were identified from a dendrogram created via flexible-beta linkage clustering analysis (beta $=-0.25$; Bray-Curtis Distance), using cover data for all taxa $(n=233)$ from all plots $(n=62)$. Indicator species analysis was used to select the most optimal grouping from the plot dendrogram, using the highest collective species indicator values (IV) among alternate groupings. Indicator species analysis was also used to identify taxa typifying the final grouping (McCune and Grace 2002). For the latter application, only taxa with an IV $>25$ and a $P$ value of $<0.05$ were considered to be significant indicators for a group (Monte Carlo tests, 9,999 randomizations).

We compared differences in composition of plant community types derived from the dendrogram with multiple response permutation procedures (MRPP), using Bray-Curtis Distance and rank transformation of the matrix (McCune and Grace 2002). We also used MRPP to compare differences in community composition among our a priori habitat classifications, among plot types, between Agrostis and non-Agrostis plots, and between GM Agrostis and non-GM Agrostis plots.

We investigated relationships between plot environmental attributes, disturbance characteristics, and vegetation metrics; and plant communities, habitats, and plot types; using non-metric multidimensional scaling (NMS), a nonparametric, indirect ordination technique. NMS analyses were conducted using BrayCurtis Distance, a random starting configuration, 250 runs with real data, and 250 runs with randomized data (McCune and Grace 2002). Pearson correlation analysis between NMS axis scores and plot values was used to identify gradients related to plant community composition.

\section{Results}

Dominant plant species in plot types and habitats

The twenty-five most abundant species across all plots, and the 10 most abundant species in each plot type and habitat, are shown in Table 2. Many of the same species were dominant in most of the plot types and habitats, although their ranking differed. In contrast to the plot types, stronger species preferences for habitats were observed. For example, Alnus rhombifolia (white alder) was found in all plot types except GM, but was only found in the Deschutes habitat, where there were no GM sites. Also, native species had notably low presence and cover in the Canal habitat, and ruderal species, especially weedy annuals, were common. 


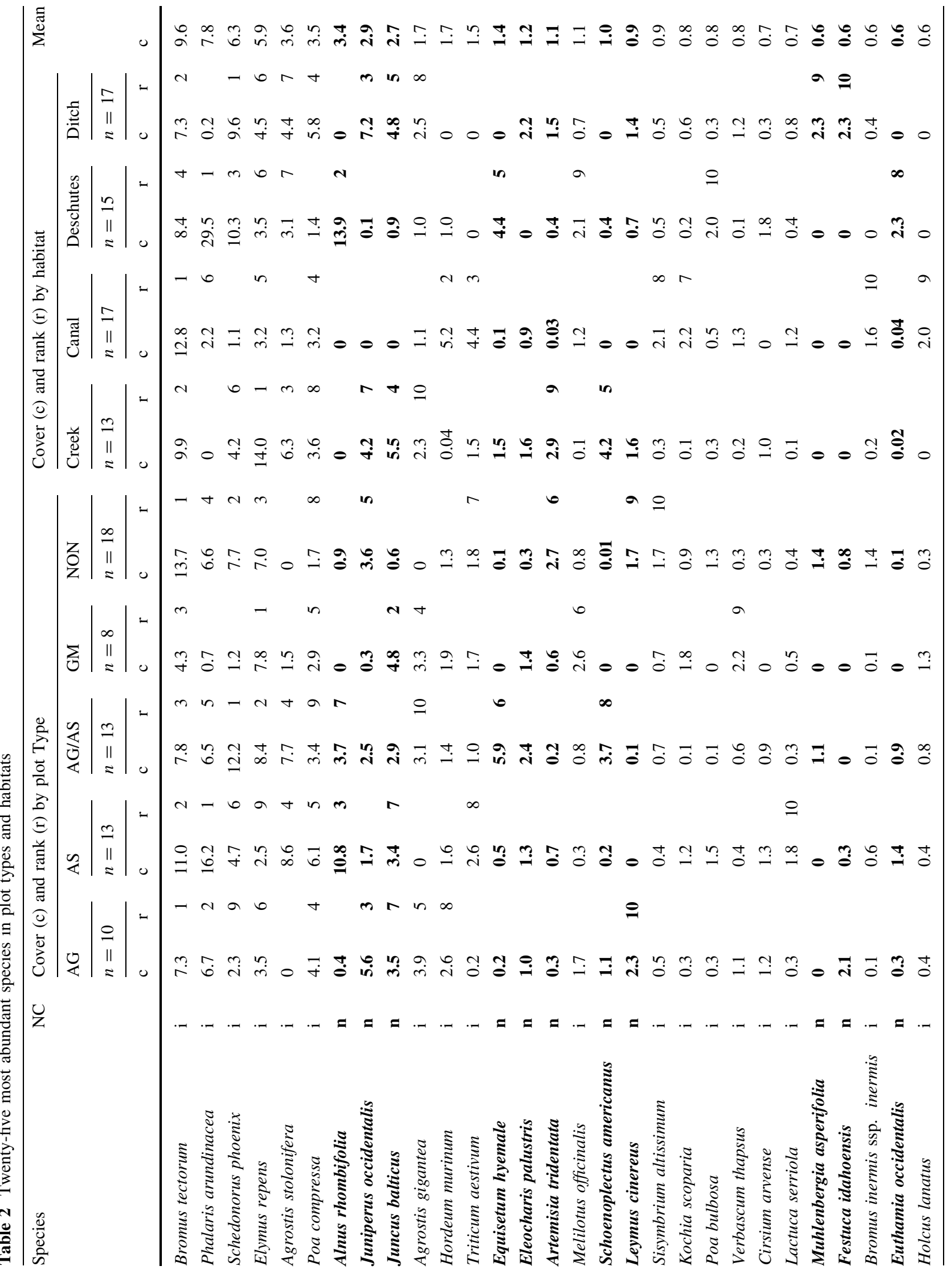




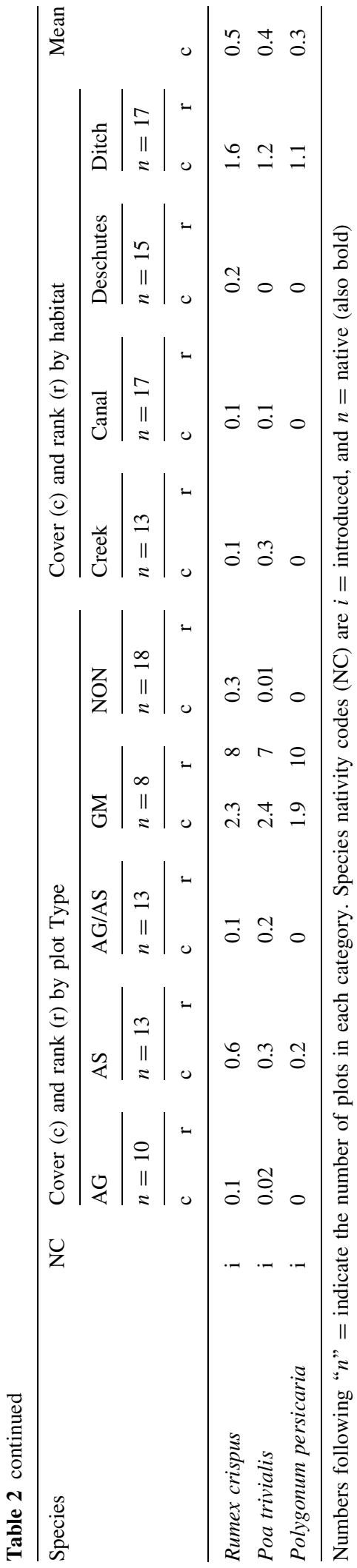

Plant communities

MRPP analyses of the plant community data in plots assigned to our four a priori habitats resulted in a chance-corrected within-group agreement $(A)$ of 0.32 , with $P<0.001$, indicating that the four habitats were floristically distinct. Similarly, MRPP analyses suggested there were floristic differences among plot types ( $A=0.09$ and $P<0.001$ ), and between Agrostis $(n=18)$ and non-Agrostis $(n=44)$ plots ( $A=0.04 ; P=0.001)$. Conversely, there were no floristic differences between GM $(n=8)$ and non-GM $(n=54)$ plots $(A=0.01 ; P=0.123)$.

Data-driven post hoc plant community classification using flexible-beta linkage clustering analysis produced a dendrogram (not shown) which resulted in 11 plant communities. MRPP analyses of these communities showed that they were floristically distinct, with $A=0.72$ and $P<0.001$. Despite MRPP results, there was considerable species overlap among plant communities, due primarily to the presence of several introduced species with broad ecological amplitudes that were widespread in the study area. Characteristic species typifying each of the 11 plant communities are shown in Online Resource 2, along with their mean cover, constancy (relative frequency of species in plots in the community), and significant indicator values (IV $>25, P<0.05$ ). The number of each of the habitats and plot types associated with each plant community are shown in Table 3 . As can be seen in Table 3, plant communities were generally aligned with the habitats assigned a priori, with the Deschutes habitat having the closest alignment. The Phalaris arundinacea-Alnus rhombifolia community was found only in the Deschutes habitat, where it occupied 14 of the 15 plots. Although several other plant communities were also found in only one habitat, none of the habitats consisted of a single plant community. The Ditch habitat was the most floristically diverse, with 7 of the 11 plant communities present, due in part to the diversity of the plot environmental settings, which included roadside ditches $(n=9)$, pond margins $(n=5)$, and springs/seeps $(n=3)$. Each of the plant communities was comprised of more than one plot type, and the Holcus lanatus-Triticum aestivumHordeum murinum plant community, found only in the Canal habitat, included all 5 plot types.

NMS ordination of the plant community data resulted in a 4-dimensional final solution (Monte 
Table 3 Plant communities, habitats, and plot types

\begin{tabular}{|c|c|c|c|c|}
\hline Code & Community & Plots $(n)$ & Habitat(s) & Plot types \\
\hline 1 & Bromus tectorum-Elymus repens & 9 & $\begin{array}{l}\text { Creek (3) } \\
\text { Canal (6) }\end{array}$ & $\begin{array}{l}\text { AG (1) } \\
\text { AS (2) } \\
\text { NON (5) } \\
\text { GM (1) }\end{array}$ \\
\hline 2 & Poa compressa-Descurainia sophia & 4 & $\begin{array}{l}\text { Canal (1) } \\
\text { Ditch (3) }\end{array}$ & $\begin{array}{l}\text { AG (1) } \\
\text { AS (1) } \\
\text { NON (2) }\end{array}$ \\
\hline 3 & $\begin{array}{l}\text { Agrostis stolonifera-Taeniatherum } \\
\text { caput-medusae }\end{array}$ & 4 & $\begin{array}{l}\text { Creek (1) } \\
\text { Deschutes (1) } \\
\text { Ditch (2) }\end{array}$ & $\begin{array}{l}\text { AG/AS (1) } \\
\text { AS (3) }\end{array}$ \\
\hline 4 & $\begin{array}{l}\text { Holcus lanatus-Triticum aestivum-Hordeum } \\
\text { murinum }\end{array}$ & 8 & Canal & $\begin{array}{l}\text { AG (1) } \\
\text { AG/AS (2) } \\
\text { AS (2) } \\
\text { NON (1) } \\
\text { GM (2) }\end{array}$ \\
\hline 5 & Agrostis gigantea-Elymus repens & 4 & $\begin{array}{l}\text { Canal (2) } \\
\text { Ditch (2) }\end{array}$ & $\begin{array}{l}\mathrm{AG}(2) \\
\mathrm{GM}(2)\end{array}$ \\
\hline 6 & Elymus repens-Salix exigua & 4 & $\begin{array}{l}\text { Creek (3) } \\
\text { Ditch (1) }\end{array}$ & $\begin{array}{l}\text { AG/AS (2) } \\
\text { NON (1) } \\
\text { GM (1) }\end{array}$ \\
\hline 7 & $\begin{array}{l}\text { Muhlenbergia asperifolia-Schedonorus } \\
\text { phoenix }\end{array}$ & 3 & Ditch & $\begin{array}{l}\text { AG/AS (1) } \\
\text { NON (2) }\end{array}$ \\
\hline 8 & Polygonum persicaria-Juncus balticus & 3 & Ditch & $\begin{array}{l}\text { AS (1) } \\
\text { GM (2) }\end{array}$ \\
\hline 9 & Schoenoplectus americanus-Cicuta douglasii & 4 & Creek & $\begin{array}{l}\text { AG (1) } \\
\text { AG/AS (3) }\end{array}$ \\
\hline 10 & Juniperus occidentalis-Festuca idahoensis & 5 & $\begin{array}{l}\text { Creek (2) } \\
\text { Ditch (3) }\end{array}$ & $\begin{array}{l}\text { AG (2) } \\
\text { AG/AS (1) } \\
\text { NON (2) }\end{array}$ \\
\hline 11 & Phalaris arundinacea-Alnus rhombifolia & 14 & Deschutes & $\begin{array}{l}\text { AG (2) } \\
\text { AG/AS (3) } \\
\text { AS (4) } \\
\text { NON (5) }\end{array}$ \\
\hline
\end{tabular}

correlated (Pearson $\left.r^{2}=0.72\right)$ with the soil moisture index (SMI). This moisture gradient was also reflected by higher cover of wetland-affiliated species, greater RWC, and higher overall cover at wetter locations. The two Agrostis-dominated communities, Agrostis stolonifera-Taeniatherum caput-medusae and Agrostis gigantea-Elymus repens, were intermediate along this moisture gradient, but were at opposing ends of a disturbance-related gradient (Axis 1), with the $A$. gigantea communities having greater disturbance than the A. stolonifera communities. This disturbance gradient was reflected by a greater incidence of roads, 
burning and herbicide spraying, and RIC in the more disturbed communities, and higher overall cover in the less disturbed communities. Overall cover was equally well correlated with both disturbance and moisture gradients. Individual plant community correlation with both gradients was evident for several communities, notably the Holcus lanatus-Triticum aestivumHordeum murinum community in the dry, high disturbance quadrant; the Schoenoplectus americanus-Cicuta douglasii community in the wet, high disturbance quadrant; and the Polygonum persicariaJuncus balticus and Phalaris arundinacea-Alnus rhombifolia communities in the wet, low disturbance quadrant. Species composition within all of the communities appeared to be driven by one or both of these gradients, although the Poa compressa-Descurainia sophia and Agrostis stolonifera-Taeniatherum caput-medusae communities (both with $n=4$ plots) included plots toward opposing ends of both gradients.

When the plots were coded with their respective habitats on the NMS ordination (Fig. 2, Panel B), one obvious trend was that the Canal plots were clustered toward the dry, high disturbance quadrant of the ordination. In contrast to the Canal plots, the Deschutes plots were clustered toward the wet, low disturbance quadrant. Also, Ditch plots formed two relatively discrete opposing clusters; one with high moisture and high disturbance, comprised of roadside ditches in agricultural areas; and the other with low moisture and low disturbance, which included ponds, springs, seeps, and roadside ditches in rangeland (shrub/steppe) settings.

When the plots were coded with their respective plot types on the NMS ordination (Fig. 2, Panel C), there were some discernable spatial trends. The $A$. gigantea (AG) plots were concentrated near the center along the moisture gradient (Axis 3 ) relative to the $A$. stolonifera (AS) plots, which extended farther toward the wetter end. The non-Agrostis (NON) plots tended toward the drier end of the moisture gradient, and the AG/AS plots tended toward the wetter end. The only separation along the axis representing the disturbance gradient was that the GM plots were predominantly at the more disturbed end.

\section{Distribution of wetland plant species}

RWC varied among plot types, habitats, and plant communities (Table 4). Among plot types, A. stolonifera plots had the greatest RWC. Non-Agrostis plots had the lowest RWC, and also had the lowest GSM. Among habitats, Deschutes sites had the highest RWC, and Canal sites had the lowest. Canal sites also had the lowest GSM, and the highest amount of bare ground, over twice that found at Deschutes sites. Among plant communities, the Polygonum persicaria-Juncus balticus plant community had the highest RWC, while the Poa compressa-Descurainia sophia community had the lowest. It is interesting that the former community had the lowest GSM of all the communities, illustrating that measuring soil moisture at one point in time is not as robust an indicator of conditions over time as is the plant assemblage present; this community was at a seasonally wet pond which was dry at the time of soil sampling. Regression analysis at the transect scale (3 transects per plot reflecting increasing distance from the water's edge or plot topographic low point) indicated a positive relationship ( $r^{2}=0.42, n=181$ ) between GSM and RWC. RWC also decreased dramatically with distance from the water's edge or topographic low point (plot baseline), as did GSM (Table 5). These trends were consistent across all plot types and habitats.

As expected, SMI values were inversely related to RWC, with the Polygonum persicaria-Juncus balticus and Schoenoplectus americanus-Cicuta douglasii plant communities having the lowest SMI (Table 4). However, the Muhlenbergia asperifolia-Schedonorus phoenix community, with relatively low RWC, had a similar SMI to the Phalaris arundinacea-Alnus rhombifolia community, which had considerably higher RWC. Regression analysis at the transect scale also showed a significant relationship between GSM and SMI $\left(r^{2}=0.44, n=181\right)$. SMI also increased dramatically with distance from the plot baseline (Table 5); this trend was consistent across all plot types and habitats.

\section{Distribution of introduced plant species}

Introduced plant species constituted a greater proportion of the vegetation at the study plots than did native species, with overall RIC $=66 \%$ (Table 4 ). Only 78 of the 233 total taxa present across all plots were introduced, indicating that the mean cover of individual introduced species was greater than the mean cover of individual native species.

Among plot types, GM plots had the greatest RIC (76\%), while RIC at the other plot types ranged from 


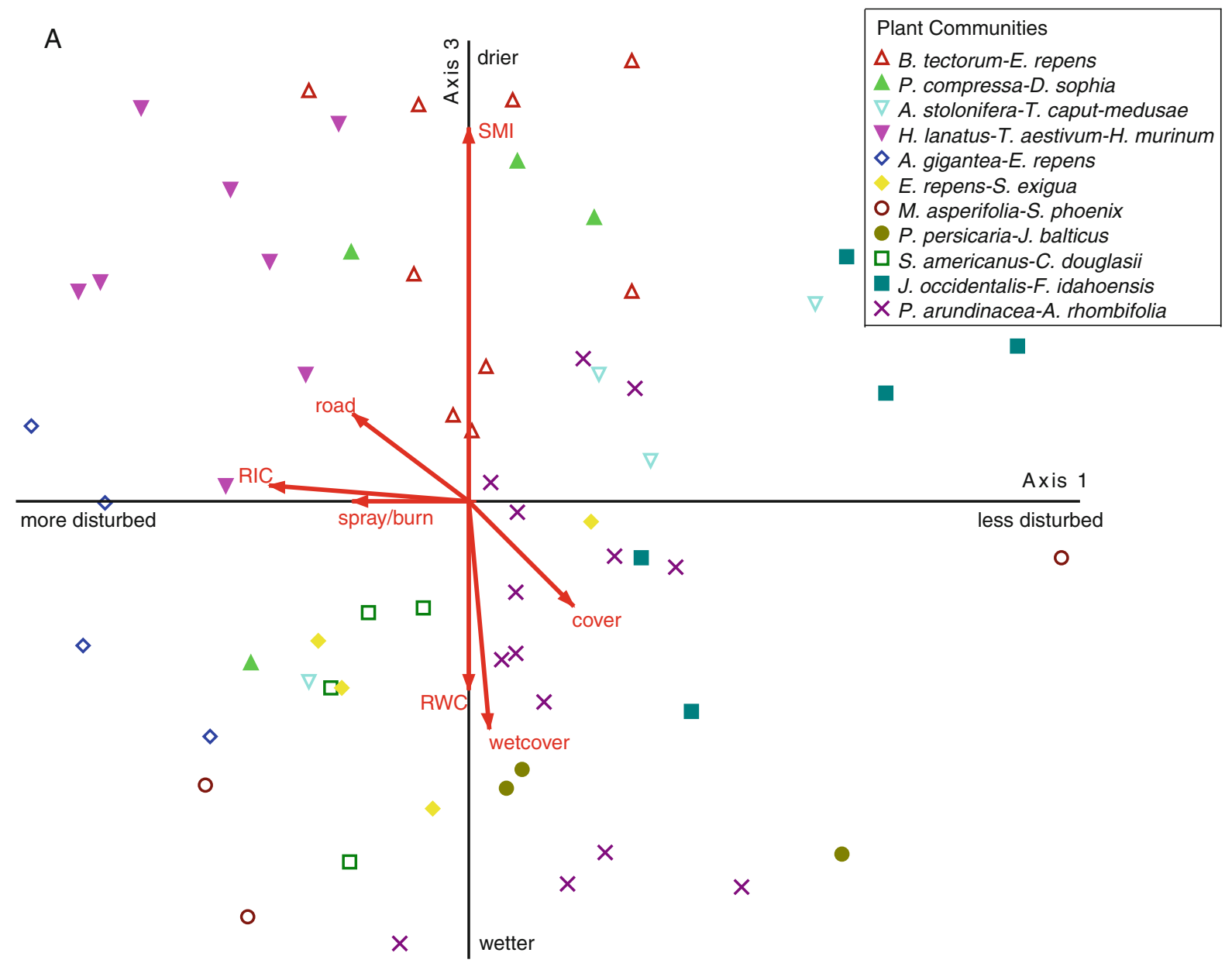

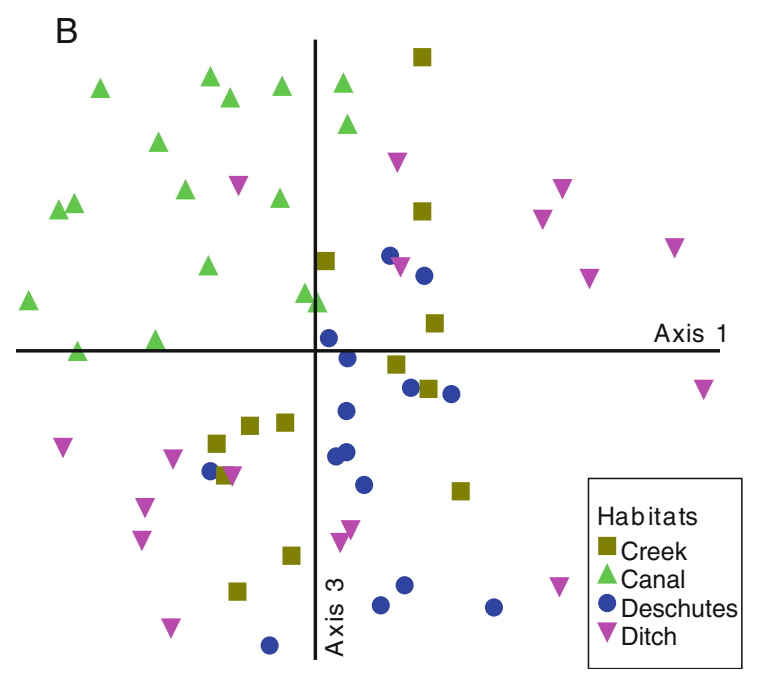

62 to $68 \%$. The GM plots also had the greatest amount of bare ground and were at the high end of the disturbance gradient on the NMS ordination,

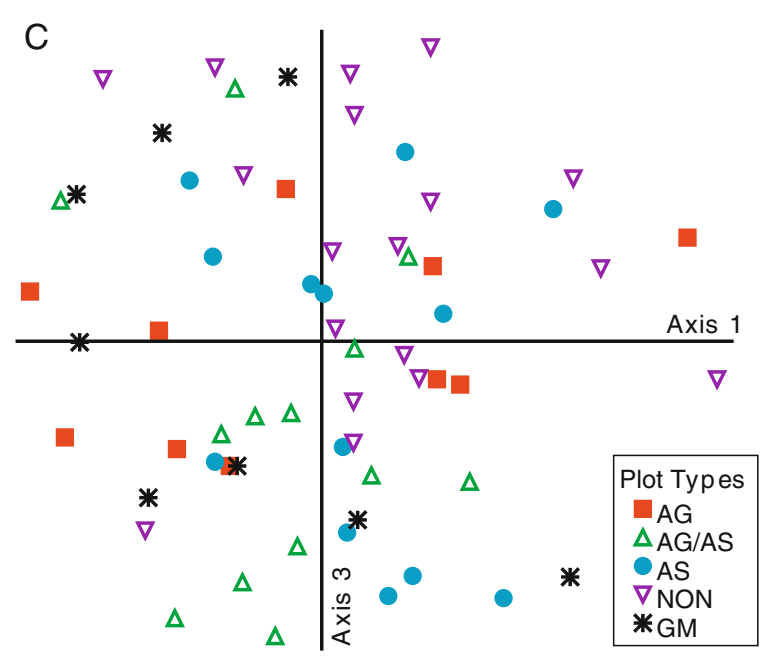

suggesting that a high disturbance regime favors GM Agrostis seedling establishment. With the exception of Canal sites $(\mathrm{RIC}=83 \%)$, all habitats had similar RIC 
Fig. 2 NMS ordination of plant communities, habitats, and plot types (233 species, 62 plots). Axis 1 represents a disturbance gradient and Axis 3 represents a moisture gradient. a (top)plant communities are denoted by both color and symbol; and vectors are environmental, disturbance, or vegetation summary variables related to NMS axes (Pearson $r^{2}>0.2$ ). Plant communities are described in Online Resource 2. b (bottom left)—habitats are denoted by both color and symbol; Creek, Canal, Deschutes, and Ditch. c (bottom right) - plot types are denoted by both color and symbol; AG, A. gigantean; AG/AS, A. gigantealA. stolonifera; $A S, A$. stolonifera; $N O N=$ non-Agrostis, and $G M=$ genetically modified Agrostis

(56-66\%). The Canal habitat also had the greatest amount of bare ground.

There was considerable variation in the proportion of introduced species among plant communities, with three communities being primarily native (RIC from
28 to $42 \%$ ) and four communities being overwhelmingly non-native (RIC from 81 to $90 \%$ ). One of these latter communities, the Holcus lanatus-Triticum aestivum-Hordeum murinum community, was comprised of 8 plots all on the banks of irrigation canals. The native-dominated Juniperus occidentalis-Festuca idahoensis community had the lowest RIC, and was at the lowest position on the disturbance gradient of the NMS joint plot.

There did not appear to be any within-plot spatial trends in RIC, even though the amount of bare ground increased dramatically with distance from the water's edge or topographic low point (Table 5). This result was consistent across all plot types and habitats. Regression analysis at the transect scale indicated that there was no general relationship between bare ground and RIC $\left(r^{2}=0.05, n=185\right)$. There was

Table 4 Plot means

\begin{tabular}{|c|c|c|c|c|c|c|c|}
\hline & Bare & GSM & AG Cover & AS Cover & RWC & SMI & RIC \\
\hline All plots & 33 & 20 & NA & NA & 39 & 3.4 & 66 \\
\hline \multicolumn{8}{|l|}{ Plot type } \\
\hline $\mathrm{AG}$ & 42 & 21 & 3.9 & - & 32 & 3.7 & 64 \\
\hline AG/AS & 29 & 25 & 3.1 & 7.7 & 48 & 3.0 & 62 \\
\hline AS & 26 & 19 & - & 8.6 & 54 & 3.1 & 68 \\
\hline NON & 31 & 17 & - & - & 26 & 3.8 & 65 \\
\hline GM & 44 & 18 & 3.3 & 1.5 & 38 & 3.5 & 76 \\
\hline \multicolumn{8}{|l|}{ Habitat } \\
\hline Creek & 33 & 21 & 2.3 & 6.3 & 36 & 3.3 & 56 \\
\hline Canal & 47 & 16 & 1.1 & 1.3 & 29 & 4.0 & 83 \\
\hline Deschutes & 21 & 24 & 1.0 & 3.1 & 56 & 2.9 & 66 \\
\hline Ditch & 30 & 20 & 2.5 & 4.4 & 36 & 3.4 & 58 \\
\hline \multicolumn{8}{|l|}{ Plant community } \\
\hline B. tectorum-E. repens & 49 & 17 & 0.1 & 0.5 & 23 & 4.0 & 73 \\
\hline P. compressa-D. sophia & 18 & 14 & 0.1 & 0.6 & 12 & 4.2 & 90 \\
\hline A. stolonifera-T. caput-medusae & 22 & 24 & 0.8 & 19.8 & 37 & 3.5 & 62 \\
\hline H. lanatus-T. aestivum-H. murinum & 42 & 15 & 0.4 & 2.1 & 33 & 4.0 & 85 \\
\hline A. gigantea-E. repens & 57 & 23 & 12.2 & 0.02 & 41 & 3.5 & 81 \\
\hline E. repens-S. exigua & 35 & 22 & 0.6 & 10.0 & 26 & 3.1 & 86 \\
\hline M. asperifolia-S. phoenix & 17 & 23 & 1.0 & 6.3 & 37 & 2.92 & 58 \\
\hline P. persicaria-J. balticus & 24 & 7 & 0 & 5.9 & 79 & 2.5 & 42 \\
\hline S. americanus - C. douglasii & 32 & 28 & 6.4 & 6.0 & 62 & 2.6 & 39 \\
\hline J. occidentalis $-F$. idahoensis & 40 & 18 & 0.5 & 0.5 & 19 & 4.0 & 28 \\
\hline P. arundinacea-A. rhombifolia & 20 & 24 & 1.1 & 1.3 & 57 & 2.94 & 64 \\
\hline
\end{tabular}

Bare bare ground, GSM gravimetric soil moisture; AG, A. gigantea; AS, A. stolonifera; $R W C$ relative wetland cover, SMI soil moisture index, and $R I C$ relative introduced cover. All values are percents except for SMI which ranges from 0 to 5 


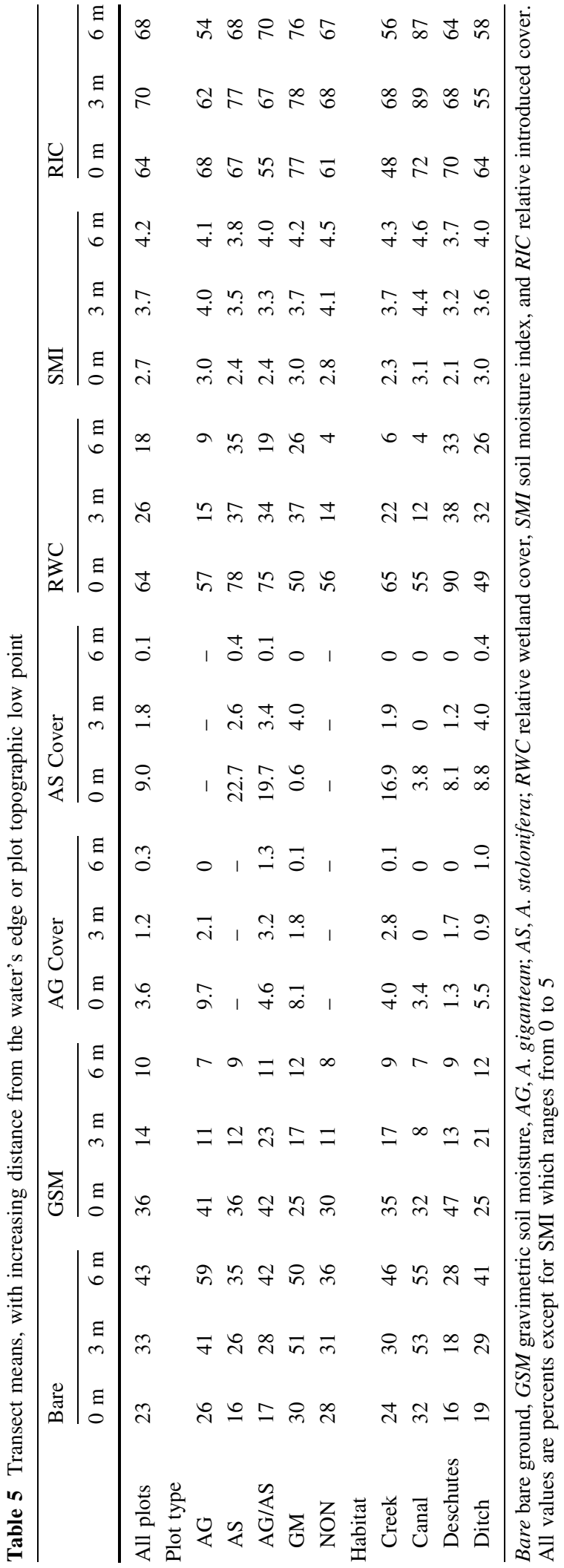

also no general relationship between GSM and RIC $\left(r^{2}=0.02, n=181\right)$.

\section{Discussion}

Wetland habitats in study plots

Wetlands are ecologically important and legally protected habitats. Wetlands typically have predominantly hydrophytic plant communities ( RWC >50\%), wetland hydrology, and hydric soils (Cowardin et al. 1979). The soil moisture index (SMI), an alternative to the Cowardin et al. (1979) system, has been highly correlated with the presence of hydric soils (Scott et al. 1989). A soil moisture index of 3.0 is considered to be the breakpoint between wetlands and uplands (Wentworth et al. 1988). Riparian zones, defined as the areas adjacent to streams, rivers, lakes, reservoirs, and other inland aquatic systems that affect or are affected by the aquatic systems, may or may not meet wetland criteria (Fischer et al. 2001). In 46 of our 62 plots, the transect adjacent to the waterway or at the plot topographic low point (plot baseline) had a hydrophytic plant community (RWC $>50 \%$ ) and SMI $<3.0$, compared to only 5 plots for the transect farthest upslope. Soils along the plot baseline were thus anticipated to be hydric. Hydric soils are typically anoxic, causing anaerobic microbial processes to replace aerobic processes, resulting in reducing rather than oxidizing conditions (Laanbroek 1990). Under reducing conditions ammonia, ferrous iron, manganese ions, hydrogen sulfide, and methane accumulate. We observed decreasing gradients of $\mathrm{Fe}(63.1,25.0$, and $19.4 \mathrm{ppm})$ and $\mathrm{NH}^{4}-\mathrm{N}$ (5.6, 3.1, and $2.9 \mathrm{ppm})$ with increasing distance $(0,3$, and $6 \mathrm{~m}$ ) from the plot baseline, and a corresponding increasing gradient of $\mathrm{NO}^{3}-\mathrm{N}(4.8,8.4$, and $9.2 \mathrm{ppm})$, suggesting that soils at the plot baseline were usually hydric.

Seven of the 15 plots in the Deschutes habitat had $>50 \%$ RWC and SMI $<3.0$, followed by 4 of 13 plots in the Creek habitat and 5 of 17 plots in the Ditch habitat. None of the plots in the Canal habitat had $>50 \%$ RWC or SMI $<3.0$. The Polygonum persicaria-Juncus balticus, Schoenoplectus americanus-Cicuta douglasii and Phalaris arundinacea-Alnus rhombifolia plant communities were all hydrophytic ( $>50 \%$ RWC), with SMI $<3.0$. Six of 13 plots in the $A$. gigantealA. stolonifera plot type, 5 of 13 plots in the $A$. 
stolonifera plot type, and 2 of 10 plots in the $A$. gigantea plot type had $>50 \%$ RWC and SMI $<3.0$. In addition, 30 of the 40 transects across all plots in which A. stolonifera was present had $>50 \%$ RWC, and 29 had SMI <3.0. Because wetlands are where $A$. stolonifera is best adapted, wetlands are where GM $A$. stolonifera is likely to be most successful. In addition, those are the locations where pollen recipients are most often present. If glyphosate is used to manage invasive species, glyphosate-resistant plants will have a strong selective advantage. Wetlands thus appear to be at high risk for potential ecological effects resulting from gene flow from glyphosate-resistant GM $A$. stolonifera into naturalized populations of Agrostis in the Madras study area, particularly where glyphosate may be applied.

Introduced species in study plots

All of the plots in the Canal, Creek, and Deschutes habitats, and most of the plots in the Ditch habitat, were in riparian areas. Riparian areas are characterized by spatially and temporally complex lateral and longitudinal gradients in: (1) moisture availability, (2) geomorphic surfaces and topography, (3) substrate complexity, and (4) disturbance regimes, creating intricate plant distribution patterns (Gregory et al. 1991). Our data reflected this complexity; for example, note the dramatic differences in the proportion of wetland-affiliated species in the 0,3 , and $6 \mathrm{~m}$ transects within the plots (Table 5). The combination of frequent disturbance and increased propagule supply may make riparian areas particularly susceptible to invasion by introduced plant species (Brown and Peet 2003; Planty-Tabacchi et al. 1996). In addition, riparian plant communities in arid grassland and shrub/steppe ecosystems in northeast Oregon, similar to our Madras study sites, had a greater richness and abundance of introduced species than those in nearby moist forested ecosystems, suggesting there may be differences in vulnerability to invasion among riparian community types (Magee et al. 2008). Riparian plant communities often include combinations of hydrophytes, ruderal species that invade following disturbances, and species adapted to rapidly drying coarsetextured substrates (Diaz and Mellen 1996). Soil binding perennial species that reproduce clonally via rhizomes (e.g., A. gigantea) or stolons (e.g., A. stolonifera) may have an added advantage in riparian areas where frequent erosion-deposition cycles produce unstable substrates. In addition, transport of stolon fragments in waterways can be a significant means of dispersal for A. stolonifera (Boedeltje et al. 2003).

It was at first surprising that regression analysis showed no relationship between bare ground and RIC in the study plots, because introduced species are often favored by disturbance, which also creates bare ground. The reason for this lack of a relationship between bare ground and RIC is that many of the study plots were dominated by introduced perennial grasses that are adapted to closed-turf or densely vegetated plant communities, including Agrostis stolonifera, Elymus repens, Phalaris arundinacea, Poa compressa, and Schedonorus phoenix. There was also no relationship between GSM and RIC, SMI and RIC, or RWC and RIC because these same perennial species are all adapted to mesic environments. These perennial grasses were the five most abundant species across all plots following Bromus tectorum, the most abundant species overall. Whereas the former grasses were all more abundant in transects nearer to the water's edge or topographic low point, Bromus tectorum, an introduced annual, was more abundant in the drier upslope transect. B. tectorum is widespread in arid shrub/steppe ecosystems throughout the intermountain west, and can be found in a broad range of riparian plant communities (Magee et al. 2008).

Because many introduced species are generalists and tend to have wider ecological amplitudes than native species in similar functional groups, the presence of introduced species is expected to lead toward floristic homogenization (Olden and Rooney 2006). This phenomenon was apparent in the Madras plant communities, where several introduced species were so widespread that it was difficult to differentiate among species groups. For example, the Bromus tectorum-Elymus repens plant community had no species with significant indicator values because the dominant species were found in nearly every other community and thus showed little fidelity to that particular plant community.

\section{A. stolonifera and A. gigantea as invasive species}

Although A. stolonifera is considered to be invasive by some sources (Weber 2003), it has been suggested that A. stolonifera is rarely invasive in natural areas 
(MacBryde 2005). This latter conclusion may have been drawn because A. stolonifera is not usually included on State or Federal invasive and/or noxious species lists, and because there is confusion about the definitions of the terms "invasive" and "naturalized" (Pyšek et al. 2004; Richardson et al. 2000). Most invasive species lists focus on species which are recent introductions or are rapidly becoming established in new habitats or geographic areas, presumably because these are the species for which efforts to slow or stop their invasion will have greater efficacy. However, some introduced forage and turf grasses have been planted extensively in the United States over a long period of time, and have "naturalized" to the extent that they may have already dispersed to, and reached equilibrium within, much of their optimal habitat. Naturalized species are often overlooked in discussions of invasive species, and typically do not appear on formal lists of noxious species, a situation which has been exploited in the debate over the use of transgenic creeping bentgrass [e.g., (Meier 2000)]. For example, Bromus tectorum (cheatgrass), Phalaris arundinacea (reed-canary grass), Daucus carota (wild carrot), and Leucanthemum vulgare (oxeye daisy), have been naturalized in Oregon for decades and are known to have substantially degraded the integrity of native plant communities and disrupted ecosystem functions. However, these species are not included on the Oregon noxious weed list (Oregon Department of Agriculture 2010).

An introduced species is considered to be invasive if it readily becomes established in natural habitats, persists, and can become widely distributed on the landscape [sensu (Pyšek et al. 2004)]. A. stolonifera and $A$. gigantea both met these criteria in wetland and riparian settings in the Madras study area, and therefore should be considered to be invasive in those habitats.

Contrasting environmental and ecological tolerances of A. gigantea and A. stolonifera

Agrostis stolonifera and A. gigantea were associated with distinct and contrasting plant communities and environmental settings. A. gigantea (AG) plots had a considerably lower proportion of wetland species, a higher SMI, and a greater amount of bare ground than A. stolonifera (AS) plots. A. gigantea plots were also concentrated near the center along the moisture gradient on the NMS ordination relative to the $A$. stolonifera plots, which extended farther toward the wetter end. In addition, A. stolonifera was associated with plant communities with greater RWC and lower SMI than the communities with which A. gigantea was associated. For example, A. gigantea was not present in the Polygonum persicaria-Juncus balticus community, which had the highest RWC and lowest SMI of any community.

In the plots where both species were present, $A$. stolonifera was more common in wetter microhabitats near the water's edge or plot topographic low point, whereas $A$. gigantea was more common in drier microhabitats upslope. This also indicates that $A$. stolonifera is better adapted to wet locations, and less adapted to dry locations, than $A$. gigantea. In addition, the communities in which A. gigantea and A. stolonifera were most abundant (Agrostis gigantea-Elymus repens and Agrostis stolonifera-Taeniatherum caputmedusae communities, respectively) occupied distinctly different positions along the disturbance gradient on the NMS joint plot (Fig. 2), with the $A$. gigantea community more common in more disturbed locations and the A. stolonifera community more common in less disturbed locations. These differences in plant communities and environmental tolerances suggest that any ecological effects of transgene flow from A. stolonifera to both A. gigantea and $A$. stolonifera will affect a greater number of habitats and plant communities than transgene flow to either one of the species alone.

Based on this and previous studies (Reichman et al. 2006; Watrud et al. 2004; Zapiola et al. 2008), riparian wetlands in the Madras, OR area are at risk of invasion by transgenic herbicide-resistant Agrostis spp. persisting following the original 2003 escape. In a similar escape from crop fields near Parma, Idaho, transgenic glyphosate resistant A. stolonifera was found across the Snake River in Oregon along irrigation canals and drainage ditches spread over $27 \mathrm{sq} \mathrm{mi}, 4$ years after the crop fields were removed (Lies 2010). For both the Parma and Madras escapes, FIFRA Sec. 24(c) Special Local Need labels were obtained by the State to apply alternative herbicides to control the escaped GM bentgrass along irrigation canals and drainage ditches. These herbicides (Finale $^{\circledR}$, glufosinate-ammonium; and Poast ${ }^{\circledR}$, sethoxydim) were not originally approved for use near irrigation water sources. The special labels also restricted the use of these herbicides to periods when canals and ditches were dry, reducing 
the effectiveness of control efforts. This situation underscores the inherent problem with introducing herbicide tolerance genes into species that are known to be naturalized or invasive. Furthermore, introducing such genes into species that are naturalized or invasive in sensitive and ecologically significant wetland and riparian habitats not only increases the threat to the integrity of those habitats, but may also negatively affect adjacent aquatic systems. Restoration of native wetland and riparian plant communities is primarily through herbicide application to selectively control introduced species, and herbicide-resistant species in these communities are likely to increase in abundance following herbicide application, hindering restoration efforts.

This type of study should be considered in risk assessments of genetically modified species with naturalized populations or naturalized genetically compatible relatives. Characterizing the communities and habitats at risk will enable informed decisions to be made regarding the management of transgenic crops.

Acknowledgments Special thanks are extended to Kate Norman (United States Fish \& Wildlife Service, Arlington, VA) for a thoughtful review of the manuscript and for assistance in creating Fig. 1, and to E. Henry Lee (United States Environmental Protection Agency, Corvallis, OR), for guidance on statistical analyses. We also appreciate the helpful comments of three anonymous reviewers. Information in this document has been funded wholly by the U.S. Environmental Protection Agency. It has been subjected to review by the National Health and Environmental Effects Research Laboratory's Western Ecology Division and approved for publication. Approval does not signify that the contents reflect the views of the Agency, nor does mention of trade names or commercial products constitute endorsement or recommendation for use.

\section{References}

Boedeltje G, Bakker JP, Bekker RM, van Groenendael JM, Soesbergen M (2003) Plant dispersal in a lowland stream in relation to occurrence and three specific life-history traits of the species in the species pool. J Ecol 91(5):855-866

Brown RL, Peet RK (2003) Diversity and invasibility of southern Appalachian plant communities. Ecology 84(1):32-39

Cowardin LM, Carter V, Golet FC, LaRoe ET (1979) Classification of wetlands and deepwater habitats of the United States. USDI Fish and Wildlife Service, Office of Biological Services, Washington, DC

Diaz NM, Mellen TK (1996) Riparian ecological types: Gifford Pinchot and Mt. Hood National Forests. Columbia River
Gorge National Scenic Area, USDA Forest Service, Pacific Northwest Region

Fischer RA, Martin CO, Ratti JT, Guidice J (2001) Riparian terminology: confusion and clarification. Army Engineer Waterways Experiment Station, Engineer Research and Development Center, Vicksburg

Gregory SV, Swanson FJ, McKee WA, Cummins KW (1991) An ecosystem perspective of riparian zones. Bioscience 41(8):540-551

Hancock J (2003) A framework for assessing the risk of transgenic crops. Bioscience 53(5):512-519

Hitchcock CL, Cronquist A, Ownbey M, Thompson JW (1969) Vascular plants of the Pacific Northwest. University of Washington Press, Seattle

Laanbroek HJ (1990) Bacterial cycling of minerals that affect plant growth in waterlogged soils: a review. Aquat Bot 38(1):109-125

Lies M (2010) Feds mum on GMO spread. Capital Press, Tumwater

MacBryde B (2005) White paper: perspective on creeping bentgrass, Agrostis stolonifera L. USDA Animal and Plant Health Inspection Service, Biotechnology Regulatory Services Riverdale, MD

Magee TK, Ringold PL, Bollman MA (2008) Alien species importance in native vegetation along wadeable streams, John Day River basin, Oregon, USA. Plant Ecol 195(2):287-307

McCune B, Grace JB (2002) Analysis of ecological communities. MjM Software, Gleneden Beach

McCune B, Mefford MJ (2006) PC-ORD. Multivariate analysis of ecological data. Version 5. MjM Software, Gleneden Beach

Meier V (2000) Development of herbicide resistant turfgrasses. In: Northeastern Weed Science Society, 54th annual meeting, Hyatt Regency, Baltimore, 4 Jan 2000

Olden JD, Rooney TP (2006) On defining and quantifying biotic homogenization. Glob Ecol Biogeogr 15(2):113-120

Oregon Department of Agriculture (2010) Noxious weed policy and classification system. Oregon Department of Agriculture, Salem

Planty-Tabacchi A-M, Tabacchi E, Naiman RJ, DeFerrari C, Decamps H (1996) Invasibility of species-rich communities in riparian zones. Conserv Biol 10(2):598-607

Pyšek P, Richardson DM, Rejmánek M, Webster GL, Williamson M, Kirschner J (2004) Alien plants in checklists and floras: towards better communication between taxonomists and ecologists. Taxon 53(1):131-143

Reichman JR, Watrud LS, Lee EH, Burdick CA, Bollman MA, Storm MJ, King GA, Mallory-Smith C (2006) Establishment of transgenic herbicide-resistant creeping bentgrass (Agrostis stolonifera L.) in nonagronomic habitats. Mol Ecol 15(13):4243-4255

Richardson DM, Pysek P, Rejmanek M, Barbour MG, Panneta FD, West CJ (2000) Naturalization and invasion of alien plants: concepts and definitions. Div Distrib 6(2):93-107

Scott ML, Slauson WL, Segelquist CA, Auble GT (1989) Correspondence between vegetation and soils in wetlands and nearby uplands. Wetlands 9(1):41-60

USDA-NRCS (2010) The PLANTS Database. National Plant Data Center. http://plants.usda.gov/ 
USFWS (1996) 1996 National list of vascular plant species that occur in wetlands. U.S. Army Corps of Engineers. https:// rsgis.crrel.usace.army.mil/NWPL_CRREL/docs/fws_lists/ 196_intro.html

Watrud LS, Lee EH, Fairbrother A, Burdick C, Reichman JR, Bollman M, Storm M, King G, Van de Water PK (2004) Evidence for landscape-level, pollen-mediated gene flow from genetically modified creeping bentgrass with CP4 EPSPS as a marker. PNAS 101(40):14533-14538
Weber E (2003) Invasive plant species of the world: a reference guide to environmental weeds. CABI Publishing, Wallingford Wentworth TR, Johnson GP, Kologiski RL (1988) Designation of wetlands by weighted averages of vegetation data: a preliminary evaluation. Water Resour Bull 24(2):389-396

Zapiola ML, Campbell CK, Butler MD, Mallory-Smith CA (2008) Escape and establishment of transgenic glyphosate resistant creeping bentgrass (Agrostis stolonifera) in Oregon, USA: a 4-year study. J Appl Ecol 45(2):486-494 